\title{
Hubungan antara Daya Tarik Iklan Instagram Nah Project dengan Keputusan Pembelian Konsumen
}

\author{
Alamsyah Nusantara Azis *, Aning Sofyan \\ Prodi Manajemen Komunikasi, Fakultas Ilmu Komunikasi, Universitas Islam \\ Bandung, Indonesia. \\ *azisalamsyah4@gmail.com , aning.sofyan@unisba.ac.id
}

\begin{abstract}
Instagram is a social media that is widely used to provide commercial product information. One of the business actors who carry out promotional activities through the Instagram media is a shoe product produced by NAH Project Bandung City, where promotional posts through Instagram that do it have an appeal that consists of meaningful, believable and dinstinctive aspects. The appeal can have implications for the attitude of the followers or reviewers of the content of photos and videos uploaded through the account $@$ nah.project. The purpose of this study was to determine the meaningful relationship with consumer purchasing decisions on Instagram @ nah.project account, believable relationship with consumer purchasing decisions on Instagram @ nah.project account and distinctive relationship with consumer purchasing decisions on Instagram @ nah.project account. The research method used in this research is a quantitative method to measure the extent of the relationship between the attractiveness of NAH project advertisements on Instagram with consumer purchasing decisions. The conclusion of this study is the results of this study indicate that there is a strong relationship between the Meaningful aspect with Consumer Purchasing Decisions, there is a very strong relationship between aspects of Purchasing with consumer purchasing decisions and There is a strong relationship between Distinctive aspects with Consumer Purchasing Decisions on NAH shoe products Project.
\end{abstract}

Keywords: Communication, Marketing, Advertising, Attraction and Instagram.

\begin{abstract}
Abstrak. Instagram merupakan salah satu media sosial yang banyak dimanfaatkan untuk memberikan informasi produk komersial. Salah satu pelaku usaha yang melakukan kegiatan promosi melalui media Instagram adalah produk sepatu yang diproduksi oleh NAH Project Kota Bandung, dimana postingan promosi melalui instagram yang dilakukannya tersebut memiliki daya tarik yang terdiri dari aspek meaningful, believable dan dinstinctive. Daya Tarik tersebut dapat memberikan implikasi sikap bagi para followers atau reviewer dari kontens foto dan video yang diunggah melalui akun @ nah.project. Adapun Tujuan penelitian ini untuk mengetahui hubungan meaningful dengan keputusan pembelian konsumen pada akun Instagram @ nah.project, hubungan believable dengan keputusan pembelian konsumen pada akun Instagram @ nah.project dan hubungan distinctive dengan keputusan pembelian konsumen pada akun Instagram @ nah.project. Metode penelitian yang di gunakan dalam penelitian ini adalah metode kuantitatif untuk mengukur sejauhmana keeratang hubungan daya Tarik iklan NAH project di Instagram dengan keputusan pembelian konsumen. Kesimpulan dari penelitian ini adalah Hasil penelitian ini menunjukkan bahwa Terdapat hubungan yang kuat antara aspek Meaningful dengan Keputusan Pembelian Konsumen, terdapat hubungan yang sangat kuat antara aspek Beliavble dengan keputusan pembelian konsumen dan Terdapat hubungan yang kuat antara aspek Distinctive dengan Keputusan Pembelian Konsumen terhadap produk sepatu NAH Project.
\end{abstract}

Kata Kunci: : Komunikasi, Pemasaran, Iklan, Daya Tarik dan Instagram. 


\section{A. Pendahuluan}

\section{Latar Belakang Masalah}

Perkembangan industri bisnis di bidang fashion dan style semakin menunjukkan potensi yang meggaairahkan bagi sektor ekonomi. Adanya pola hidup masyarakat seperti di kawasan perkotaan dimana aktivitas lebih sering dilakukan di luar rumah, menjadikan kebutuhan makanan dan fashion dan style selalu dilakukan di luar rumah pula. Kondisi ini membuat adanya peningkatan permintaan masyarakat terhadap makanan jadi. Kebiasaan makan di luar rumah yang berkembang saat ini mengakibatkan jumlah online di Indonesia mengalami pertumbuhan. Peningakatan permintaan akan makanan jadi menjadi peluang bagi pengusaha untuk membuka bisnis online.

Pelaksanaan kegiatan bisnis berbasis online selain dari dinamika perkembangan teknologi juga terjadi karena persaingan bisnis yang terjadi. Kendati persaingan dalam bisnis ini cukup ketat, dengan inovasi yang cerdik maka pelaku usaha lokal dapat terus bersaing. Strategi inovasi dimaksud bisa dilakukan dalam berbagai aspek, mulai dari mencari desain yang unik berbeda dari yang lain, dari segi bahan baku, hingga sepatu fungsionil yang pemainnya belum terlalu banyak. Selain itu, persaingan tersebut dapat pula diatasi dengan sistem pemsaran yang tepat dan efektif seperti penggunaan media online. Dalam hal ini, pihak produsen menggunakan media on line untuk mengefektifkan dan mengefisiensikan biaya pemasaran produknya.

Salah satunya perusahaan yang bergerak di bidang fashion dan style khususnya pda produk sepetu berbasis online di Kota Bandung adalah NAH Project Sepatu yang menjadikan media Instagram sebagai media komunikasi pemasaran yang dilakukannya. (Sumber : Observasi yang dilakukan penulis, 2019). Sampai saat ini, akun instagram NAH Project Sepatu yang bernama @nah.project telah memiliki 165 ribu followers. (Sumber : Observasi yang dilakukan penulis, 2019).

Pemilihan media Instagram yang dilakukan NAH Project Sepatu dalam memasarkan produknya pun tidak lepas dari dinamika perkembangan bisnis berbasis online tersebut. Dengan demikian, maka untuk mengukur efektivitas kegiatan pemasarana melalui media Instagram yang dilakukan NAH Project, hal ini harus diukur melalui 3 indikator daya Tarik iklan yaitu meaningful, believable dan distinctive. Instagram merupakan media sosial yang memiliki fiturfitur membagikan foto serta memberikan caption dan hashtag, instagram sendiri menjadi sebuah media sosial untuk saling berkomunikasi dan berbagi informasi secara cepat disertai dengan foto kejadian. Oleh karena itu, media Instagram sangat memungkinkan memberikan peluang besar untuk meingkatkan daya Tarik suatu produk.

Pemesanan online dari media intsgram yang dimanfaatkan NAH Project Sepatu datang dari hampir dari semua provinsi di Indonesia. Sampai saat ini, NAH Project Sepatu telah mengeluarkan 20 model sepatu yang memiliki kekhasan tersendiri dan lebih dari 15 aksesoris. Terkait hal tersebut, penelitian ini melihat hubungan antara strategi pemasaran NAH Project Sepatu melalui Instagram dan minat beli para konsumen khususnya yang berada di Kota Bandung.

\section{Pertanyaan Penelitian}

1. Apakah terdapat hubungan meaningful dengan keputusan pembelian konsumen pada akun Instagram @ nah.project ?

2. Apakah terdapat hubungan believable dengan keputusan pembelian konsumen pada akun Instagram @ nah.project?

3. Apakah terdapat hubungan distinctive dengan keputusan pembelian konsumen pada akun Instagram @ nah.project?

\section{B. Landasan Teori}

Komunikasi merupakan sebuah proses sosial yang terjadi antara paling sedikit dua orang dimana seseorang mengirimkan sejumlah simbol tertentu kepada orang lain (Kennedy dan Soemanagara, 2006: 4). Komunikasi pemasaran merupakan dialog interaktif antara perusahaan 
dan pelanggannya yang berlangsung selama tahap pra-penjualan, penjualan, pemakaian, dan pasca-pemakaian (Kotler dan Armstong, 2003: 248). Komunikasi pemasaran sangat penting bagi pemasar atau perusahaan. Tanpa komunikasi, konsumen maupun masyarakat keseluruhan tidak akan mengetahui keberadaan produk dan jasa. Komunikasi pemasaran adalah suatu aktivitas yang berusaha menyebarkan informasi, mempengaruhi atau membujuk dan mengigatkan pasar sasaran atas perusahaan dan produknya agar bersedia menerima, membeli, dan loyal pada produk yang ditawarkan perusahaan yang bersangkutan (Tjipono, 2005: 45).

Komunikasi pemasaran dapat diimplementasikan dalam manajemen pemasaran, dimana manajemen pemasaran tersebut mengenal empat strategi pemasaran yang lazim disebut bauran pemasaran barang 4P, yaitu product (produk), price (harga), place (tempat, distribusi). Menurut Kotler dan Amstrong, (2012:75) dalm buku Manajemen Komunikasi dan Pemasaran, mereka menjelaskan ada empat komponen dalam bauran pemasaran sebagai berikut :

1. Product (Produk)

2. Price (Harga)

3. Place (Tempat,distribusi)

4. Promotion (Promosi)

Promosi adalah suatu unsur yang digunakan untuk memberitahukan dan mebujuk pasar tentang produk atau jasa yang baru pada perusahaan, hak dengan iklan, penjualan pribadim promosi penjualan maupun dengan publisitas. Media Promosi adalah sarana yang digunakan untuk mengkomunikasikan suatu produk atau jasa ataupun yang lain untuk dapat lebih dikenal masyarakat lebih luas salah satunya melalui instagram.

Instagram adalah sebuah aplikasi dari Smartphone yang khusus untuk media sosial yang merupakan salah satu dari media digital yang mempunyai fungsi hampir sama dengan twitter, namun perbedaannya terletak pada pengambilan foto dalam bentuk atau tempat untuk berbagi informasi terhadap penggunanya. Instagram juga dapat memberikan inspirasi bagi penggunanya dan juga dapat meningkatkan kreatifitas, karena Instagram mempunyai fitur yang dapat membuat foto menjadi lebih indah, lebih artistik dan menjadi lebih bagus (Atmoko, 2012:10).

Instagram merupakan salah satu media sosial yang saat ini sedang sangat diminati. Hal ini dikarenakan Instagram berhasil meraih kepopulerannya tak lain karena kebiasaan masyarakat sekarang yang cenderung "narsis". Dimanapun dan kapanpun kita dapat berfoto lalu mengunggahnya di Instagram. Bukan hanya foto pribadi, foto makanan, serta tempat-tempat umum yang biasanya memiliki daya tarik juga tidak pernah lepas untuk menjadi sasaran pengguna Instagram untuk difoto. Instagram adalah sebuah media sosial baru yang sengaja diciptakan untuk berbagi foto ataupun video dengan berbaga keunggulan yang menunjang keberadaannya.

Makin populernya Instagram sebagai aplikasi yang digunakan untuk membagikan foto membuat banyak pengguna yang terjun ke bisnis online turut mempromosikan produkproduknya lewat Instagram. Dan bisa disimpulkan Instagram merupakan salah satu media jejaring sosial yang dapat dimanfaatkan sebagai media pemasaran langsung. Melalui Instagramlah produk barang atau jasa ditawarkan dengan mengunggah foto atau video singkat, sehingga para calon konsumen dapat melihat jenis-jenis barang atau jasa yang ditawarkan (M Nisrina, 2015: 137).

Pengelola pemasaran hingga kini masih ada yang beranggapan bahwa kegiatan promosi yang paling efektif adalah beriklan melalui media massa. Perusahaan-perusahaan mulai bergerak menuju proses yang disebut dengan komunikasi pemasaran terpadu atau Integrated Marketing Communication (IMC), yang mencakup upaya koordinasi dari berbagai elemen promosi dan kegiatan pemasaran lainnya. Ketika penanggung jawab pemasaran di berbagai perusahaan mulai menerapkan konsep komunikasi pemasaran terpadu, mereka juga meminta biro iklan untuk mengoordinasikan penggunaan berbagai instrument promosi yang tersedia dan tidak hanya mengandalkan pada iklan di media massa." (Morrisan, 2015:7).

Daya tarik iklan (advertising appeal) mengacu pada pendekatan yang digunakan untuk menarik perhatian dan juga kesadaran konsumen dan/atau memengaruhi perasaan mereka terhadap suatu produk. Menurut Kotler \& Armstrong (2004: 643), daya tarik iklan (advertising appeals) harus mempunyai tiga sifat: 
1. Iklan harus bermakna (meaningful), menunjukkan manfaat yang membuat konsumen lebih tertarik dan menginginkan produk tersebut.

2. Iklan harus dapat dipercaya (believable), konsumen harus percaya bahwa produk tersebut memberikan informasi yang benar dan manfaat seperti yang dijanjikan. Proses believable memang tidaklah mudah karena banyak konsumen yang meragukan kebenaran iklan.

3. Iklan harus memiliki ciri khas dan berbeda (distinctive), sehingga membuat produk lebih baik dibandingkan produk kompetitor.

Setelah iklan tersebut bisa menarik perhatian dari konsumen, maka dibutuhkan kesadaran terhadap merk, dimana nantinya ini akan berdampak efek yang dihasilkan dari sebuah iklan seperti keputusan pembelian yang dilakukan konsumen terhadap produk yang diiklankan.

Keputusan pembelian konsumen adalah membeli merek yang paling disukai, tetapi dua faktor bisa berada diatara niat pembelian dan keputusan pembelian (purchase decision). Faktor pertama adalah sikap orang lain. jika seseorang yang mempunyai arti penting bagi kita berpikir bahwa seharusnya kita membeli barang yang paling murah, maka peluang kita untuk membeli barang yang mahal berkurang. Faktor kedua adalah faktor situasional yang tidak diharapkan. Konsumen mungkin membentuk niat pembelian berdasarkan faktor-faktor seperti pendapatan, harga,dan manfaat produk yang diharapkan. Namun, kejadian tak terdugaa bisa mengubah niat pembelian. Sebagai conoh : ekonomi yang memburuk, seorang teman mungkin memebritahu kita bahwa ia pernah kecewa dengan barang itu.

\section{Hasil Penelitian dan Pembahasan}

Pelaksanaan komunikasi pemasaran terpadu atau bauran Promosi yang dilakukan NAH Project dilakukan oleh tim yang menghandle dalam penyampaian pesan secara online melalui ads Instagram. Dalam hal ini, peneliti mengukur daya tarik promosi di media Instagram dari unsur meaningful, believable dan distinctive.

Berdasarkan hasil pengolahan kuesioner untuk aspek meaningful, maka didapat bahwa total skor jawaban kuisioner responden terkait iklan produk sepatu NAH Project yang ditayangkan akun@nahprpoject pada media Instagram dari aspek meaningful memiliki skor 1068 dari total skor 1365 atau sebesar 78.24\%. Skor tersebut sebagaimana yang dapat dilihat pada garis kontinum berada pada interval baik, maka dengan demikian dapat dikatakan bahwa iklan produk sepatu NAH Project yang ditayangkan akun @ nah.project pada media Instagram telah menunjukkan manfaat yang membuat konsumen lebih tertarik dan menginginkan produk tersebut secara baik.

Untuk aspek believable, terlihat bahwa total skor jawaban kuisioner responden terkait iklan produk sepatu NAH Project yang ditayangkan akun@ @ nah.project pada media Instagram dari aspek believable memiliki skor 1049 dari total skor 1365 atau sebesar76.84\%. Skor tersebut sebagaimana yang dapat dilihat pada garis kontinum berada pada interval baik, maka dapat dikatakan bahwa iklan produk sepatu NAH Project yang ditayangkan akun @ nah.project pada media Instagram telah produk tersebut memberikan informasi yang benar dan manfaat seperti yang dijanjikan secara baik.

Kemudian dari aspek distinctive, terlihat bahwa total skor jawaban kuisioner responden terkait iklan produk sepatu NAH Project yang ditayangkan akun @nah.project pada media Instagram dari aspek Distinctive memiliki skor 1750 dari total skor 2275 atau sebesar $76.92 \%$. Skor tersebut sebagaimana yang dapat dilihat pada garis kontinum berada pada interval baik, maka dapat dikatakan bahwa iklan produk sepatu NAH Project yang ditayangkan akun @ nah.project pada media Instagram memiliki ciri khas dan berbeda (distinctive), sehingga membuat produk lebih baik dibandingkan produk kompetitor secara baik. Sedangkan skor jawaban kuisioner responden terkait keputusan pembelian konsumen memiliki skor 2127 dari total skor 2730 atau sebesar $77.91 \%$. Skor tersebut sebagaimana yang dapat dilihat pada garis kontinum berada pada interval baik, maka dengan demikian dapat dikatakan bahwa iklan produk sepatu yang ditayangkan akun @ nah.project pada media Instagram dapat memberikan dampak terhadap sikap para followers atau reviewers untuk memutuskan membeli produk NAH Project.

Berdasarkan hasil output SPSS Seri 20 mengenai hubungan meaningful dengan keputusan pembelian konsumen melalui uji rank Spearman, maka deskripsi kesimpulan 
hipotesis dapat dilihat pada tabel berikut :

Tabel 1. Hubungan antara Meaningful (X1) dengan Keputusan Pembelian (Y)

\begin{tabular}{|c|c|c|c|c|}
\hline Variabel & $\mathrm{t}_{\text {hitung }}$ & $\mathrm{t}_{(0,05 ; 65)}$ & Kesimpulan & Keterangan \\
\hline $\begin{array}{c}\text { Meaningful } \\
\text { dengan } \\
\text { Keputusan } \\
\text { Pembelian }\end{array}$ & 9,756 & 2.447 & Ho ditolak & Signifikan \\
\hline
\end{tabular}

Sumber : Pengolahan Data penulis, 2019.

Berdasarkan tabel 4.28 di atas dapat dilihat bahwa koefisien korelasi Rank Spearman (Rs) adalah sebesar 0,420. Kemudian hasil dari uji signifikansi diperoleh nilai thitung sebesar 9,756 dan nilai ttabel ( $\mathrm{df}=6$ dan $\alpha=5 \%$ ) adalah sebesar 2,447. Maka dapat dilihat bahwa thitung $(9,756)>$ ttabel $(2,447)$ sehingga menyatakan bahwa Ho ditolak. Selain itu jika dilihat berdasarkan Kriteria Penarikan Kesimpulan Rakhmat, koefisien korelasi sebesar 0,420 berada di antara kriteria 0.400 - 0.599 yang menunjukkan bahwa ada hubungan yang kuat diantara dua variabel tersebut.

Berdasarkan hasil output SPSS Seri 20 mengenai hubungan Believable dengan keputusan pembelian konsumen melalui uji rank Spearman, maka deskripsi kesimpulan hipotesis dapat dilihat pada tabel berikut :

Tabel 2. Hubungan antara Believable (X2) dengan Keputusan Pembelian (Y)

\begin{tabular}{|c|c|c|c|c|}
\hline Variabel & $\mathrm{t}_{\text {hitung }}$ & $\mathrm{t}_{(0,05 ; 65)}$ & Kesimpulan & Keterangan \\
\hline $\begin{array}{c}\text { Distinctive } \\
\text { dengan } \\
\text { Keputusan } \\
\text { Pembelian }\end{array}$ & 9.224 & 2.447 & Ho ditolak & Signifikan \\
\hline
\end{tabular}

Sumber : Pengolahan Data penulis, 2019.

Berdasarkan tabel 4.30 di atas dapat dilihat bahwa koefisien korelasi Rank Spearman (Rs) adalah sebesar 0,606. Kemudian hasil dari uji signifikansi diperoleh nilai thitung sebesar 5,611 dan nilai ttabel ( $\mathrm{df}=6$ dan $\alpha=5 \%$ ) adalah sebesar 2,447. Maka dapat dilihat bahwa thitung $(5,611)>$ ttabel $(2,447)$ sehingga menyatakan bahwa Ho ditolak. Selain itu jika dilihat berdasarkan Kriteria Penarikan Kesimpulan, koefisien korelasi sebesar 0,606 berada di antara kriteria $0.600-0.999$ yang menunjukkan bahwa ada hubungan yang sangat kuat diantara dua variabel tersebut. Sehingga berdasarkan tabel 4.19 tersebut dapat disimpulkan bahwa terdapat hubungan yang sangat kuat antara Believable dengan Keputusan Pembelian Konsumen.

Berdasarkan hasil output SPSS Seri 20 mengenai hubungan Distinctive dengan keputusan pembelian konsumen melalui uji rank Spearman, maka deskripsi kesimpulan hipotesis dapat dilihat pada tabel berikut :

Tabel 3. Hubungan antara Distinctive (X3) dengan Keputusan Pembelian (Y)

\begin{tabular}{|c|c|c|c|c|}
\hline Variabel & $\mathrm{t}_{\text {hitung }}$ & $\mathrm{t}_{(0,05 ; 65)}$ & Kesimpulan & Keterangan \\
\hline $\begin{array}{c}\text { Bealivablede } \\
\text { ngan } \\
\begin{array}{c}\text { Keputusan } \\
\text { Pembelian }\end{array}\end{array}$ & 5,611 & 2.447 & Ho ditolak & Signifikan \\
\hline
\end{tabular}

Sumber : Pengolahan Data penulis, 2019.

Berdasarkan tabel 4.32 di atas dapat dilihat bahwa koefisien korelasi Rank Spearman 
(Rs) adalah sebesar 0,546. Kemudian hasil dari uji signifikansi diperoleh nilai thitung sebesar 9,224 dan nilai ttabel $(\mathrm{df}=6$ dan $\alpha=5 \%)$ adalah sebesar 2,447. Maka dapat dilihat bahwa thitung $(9,224)>$ ttabel $(2,447)$ sehingga menyatakan bahwa Ho ditolak. Selain itu jika dilihat berdasarkan Kriteria Penarikan Kesimpulan, koefisien korelasi sebesar 0,606 berada di antara kriteria 0.400-0.599 yang menunjukkan bahwa ada hubungan yang kuat diantara dua variabel tersebut. Sehingga berdasarkan tabel 4.19 tersebut dapat disimpulkan bahwa terdapat hubungan yang kuat antara Distinctive dengan Keputusan Pembelian Konsumen.

\section{Kesimpulan}

Berdasarkan hasil analisis dan pembahasan, maka peneliti memberikan kesimpulan sebagai berikut:

1. Terdapat hubungan yang kuat antara aspek Meaningful dengan Keputusan Pembelian Konsumen terhadap produk sepatu NAH Project yang merupakan Followers akun instagram @ nah.project tahun 2019. Dengan demikian, maka dapat dikatakan bahwa indikator-indikator pada Meaningful seperti informasi yang bermanfaat dan juga ketertarikan terhadap produk ini memiliki hubungan dengan keputusan pembelian konsumen.

2. Terdapat hubungan yang sangat kuat antara aspek Believable dengan Keputusan Pembelian Konsumen terhadap produk sepatu NAH Project yang merupakan Followers akun instagram @nah.project tahun 2019. Dengan demikian, maka dapat dikatakan bahwa indikator-indikator pada Believable seperti manfaat produk dan informasi yang dapat dipercaya ini memiliki hubungan dengan keputusan pembelian konsumen.

3. Terdapat hubungan yang kuat antara aspek Distinctive dengan Keputusan Pembelian Konsumen terhadap produk sepatu NAH Project yang merupakan Followers akun instagram@nah.project tahun 2019. Dengan demikian, maka dapat dikatakan bahwa indikator-indikator pada Distinctive seperti keunggulan dan ciri khas produk memiliki hubungan dengan keputusan pembelian konsumen.

\section{Daftar Pustaka}

[1] Anne Ratnasari, 2017. Promosi Penjualan Produk Melalui Instagram. Jurnal Inter Komunikasi Volume II No.2

[2] Armstrong dan Philip Kotler. 2003. Manajemen Pemasaran, Edisi Kesembilan. Jakarta: PT.Indeks Gramedia.

[3] Armstrong, dan Kotler 2003. Dasar-dasar Pemasaran, Jilid 1, Edisi Kesembilan" Jakarta : Indeks Gramedia.

[4] Atmoko Dwi, Bambang. 2012. Instagram Handbook Tips Fotografi Ponsel. Jakarta: Media Kita.

[5] Fandy Tjiptono, 2005, Pemasaran Jasa, Yogyakarta ; Penerbit. Bayumedia Publishing.

[6] Handayani, Tri. 2012. Bauran Pemasaran. Edisi 12, Jilid 2. Jakarta : Erlangga.

[7] M Nisrina. 2015. Bisnis Online, Manfaat Media Sosial Dalam Meraup Uang. Yogyakarta: Kobis.

[8] Mulyana, Deddy. 2005. Ilmu Komunikasi Suatu Pengantar. Bandung : Remaja Rosdakarya.

[9] Kennedy, John. E; R Dermawan Soemanagara., 2006. Marketing Communication - Taktik dan Strategi. Jakarta. PT Buana Ilmu Populer (kelompok Gramedia)

[10] Kotler, dan Keller. 2012. Manajemen Pemasaran. Edisi 12. Jakarta: Erlangga

[11] Kotler, Philip and Gary Armstrong. 2012. Prinsip-prinsip Pemasaran. Edisi 13. Jilid 1. Jakarta: Erlangga.

[12] Nasrullah, Rulli. 2015. Media Sosial. Bandung: PT Remaja Rosdakarya 